\title{
DOES THE HISTOLOGICAL STRUCTURE OF SPERMOVIDUCT AND FREE OVIDUCT CORRESPOND WITH THE REPRODUCTIVE MODE IN CLAUSILIIDS (GASTROPODA: PULMONATA: BALEINAE)?
}

\author{
TOMASZ K. MALTZ ${ }^{*}$, ANNA SULIKOWSKA-DROZD², IZABELA JĘDRZEJOWSKA ${ }^{3}$
}

\author{
${ }^{1}$ Museum of Natural History, University of Wrocław, Sienkiewicza 21, 50-335 Wrocław, Poland \\ (e-mail: tomasz.maltz@uni.wroc.pl) \\ ${ }^{2}$ Department of Invertebrate Zoology and Hydrobiology, University of Łódź, Banacha 12/16, 90-237 Łódź, \\ Poland \\ ${ }^{3}$ Department of Animal Developmental Biology, Institute of Experimental Biology, University of Wrocław, \\ Sienkiewicza 21, 50-335 Wrocław, Poland \\ *corresponding author
}

ABSTRACT: Spermoviduct and free oviduct of four species of Baleinae door snails of different reproductive strategy: Laciniaria plicata (oviparity), Vestia gulo (egg retention), Alinda biplicata and Vestia turgida (viviparity), were histologically examined. The spermoviduct contains three partly connected canals: autospermiduct, allospermiduct and oviduct. Their walls are built of pseudostratified epithelium which is composed of large, columnar cells and small, much thinner, supporting cells with the apical surface provided with cellular processes. The free oviduct includes two partly connected canals: oviduct and allospermiduct, with their walls also built of pseudostratified epithelium. Both morphology and secretory activity of epithelial cells are very similar in viviparous and oviparous forms.

KEY WORDS: Clausiliidae, reproductive system, Alinda, Laciniaria, Vestia, land snails

\section{INTRODUCTION}

The Baleinae are one of the five subfamilies of European clausiliids; they include seven genera with 54 species (NORDSIECK 2007). Till now, life cycles of nine Baleinae species (ca. 17\% of all species) have been studied partly or completely (FRÖMMING 1954, PIECHOCKI 1982, BAUR A. 1990, BAUR B. 1994, WIRTH et al. 1997, MARZEC 2006, MALTZ \& SULIKOWSKADROZD 2008, 2011, 2012, 2014, SULIKOWSKA-DROZD 2008, 2009, SULIKOWSKA-DROZD \& MALTZ 2012a, b, 2013, SULIKOWSKA-DROZD et al. 2012, 2013). Based on laboratory and field observations, it was shown that the animals are iteroparous, long-lived, with determinate growth (shell growth terminates with completion of the closing apparatus) and delayed reproductive maturation (reproductive system becomes morphologically fully developed 4-5 months after shell growth completion). There are inter- specific differences in their reproductive strategies. Four species are oviparous: Bulgarica cana, Balea stabilis, Laciniaria plicata and Vestia ranojevici, three: Balea fallax, Vestia gulo and V. elata, retain their eggs for a shorter or longer time, while another three: Alinda biplicata, Balea perversa and Vestia turgida, are viviparous (lecitotrophic viviparity sensu BLACKBURN 1999 or ovoviviparity sensu TOMPA 1984 and HELLER 2001).

The anatomy of the reproductive system of most Baleinae is well known, and data on its structure are mainly presented in the systematic and/or phylogenetic context (e.g. STEENBERG 1914, LIKHAREV 1962, HUDEC 1963, LUPU 1980, SCHILEYKO 2000, NORDSIECK 2007), whereas information on the histological structure of clausiliid reproductive system is scanty. There are no published comparative data on the histological structure of the reproductive sys- 
tem of closely related species with different reproductive strategies. STEENBERG's (1914) paper, published one hundred years ago, is still the main source of information on the histology of clausiliid reproductive system. The histological structure presented there is based on studies on Cochlodina laminata and Macrogastra ventricosa - oviparous representatives of Alopiinae and Clausiliinae, respectively. The present knowledge of the histological structure of the clausiliid reproductive organs is not much greater than that presented by STEENBERG (1914), since the same data are cited in LIKHAREV's (1962) monograph, while the information in NORDSIECK's $(1966,1985,2007)$ papers is enigmatic and pertains to anatomy rather than histology. The recent studies on the histology of the reproductive system of Ruthenica filograna - subfamily Clausiliinae (SZYBIAK \& GABAEA 2013) corroborate STEENBERG's (1914) observations, especially regarding the structure of spermoviduct and free oviduct in the representatives of the subfamily.

The objective of this paper was to check if the diversity of reproductive strategies among closely relat- ed Baleinae was reflected in the histological structure of their reproductive system. We hypothesised that the different reproductive strategies demand different physiological adaptations, for instance the possibility of gas exchange for developing embryo in viviparous species. It is likely that physiological differences are expressed in the histology by increased number or activity of certain cell types. Among invertebrates such physiological modifications in the epithelia of female reproductive system have been reported (e.g. WEYGOLDT 1969, FARLEY 1998, JĘDRZEJOWSKA et al. 2013). In gastropods data concerning this issue are lacking. Since dissection of egg-filled reproductive systems of viviparous/egg retaining Baleinae (SULIKOWSKA-DROZD 2009, MALTZ \& SULIKOWSKADROZD 2012) corroborated STEENBERG's (1914) observation that the eggs were retained in a pocket, formed by the lower part of the spermoviduct and the free oviduct of clausiliids, special attention was paid to these two organs.

material was dehydrated in a graded alcohol series and xylene, embedded in paraffin (Paraplast Plus with $8 \%$ DMSO) and cut on a rotational microtome into $7 \mu \mathrm{m}$ thick sections (serial sections attached to hot microscopic slides). Following rehydration, the slides with sections were stained with Delafield hematoxylin and $25 \%$ aqueous solution of eosin (ZAWISTOWSKI 1986), dehydrated, cleared and coverslipped with DPX mounting medium for light microscope observations (Olympus BHS). Two organs: spermoviduct and free oviduct, were subjected to detailed histological analysis focused on the structure of the lining epithelium. The same acronyms for the specific structures were used throughout the text and Figures 1-3.

\section{RESULTS AND DISCUSSION}

The main organs of the Baleinae reproductive system are typical of hermaphroditic Stylommatophora (NORDSIECK 1985, GómEZ 2001) (Fig. 1A). Spermoviduct (so) and free oviduct (fov) were regarded as especially important for the comparative analysis of the organs and structures of species with different reproductive strategies, as these organs provide a space for long-term storage of developing embryos in viviparous species, while in oviparous snails they serve only as a channel for transportation of eggs towards the genital orifice.

\section{SPERMOVIDUCT}

In all four analysed species the spermoviduct is internally divided into three partly connected canals (Fig. 1B) two of which are located close to the prostate. This confirms STEENBERG's (1914) observation that the spermoviduct (so) is composed of three parts, separated by incomplete partitions: 1. large, mucous canal (in this report referred to as oviduct; ov); 2. narrow canal (=allospermiduct; als) and 3. seminal canal (=autospermiduct; aus), to whose 


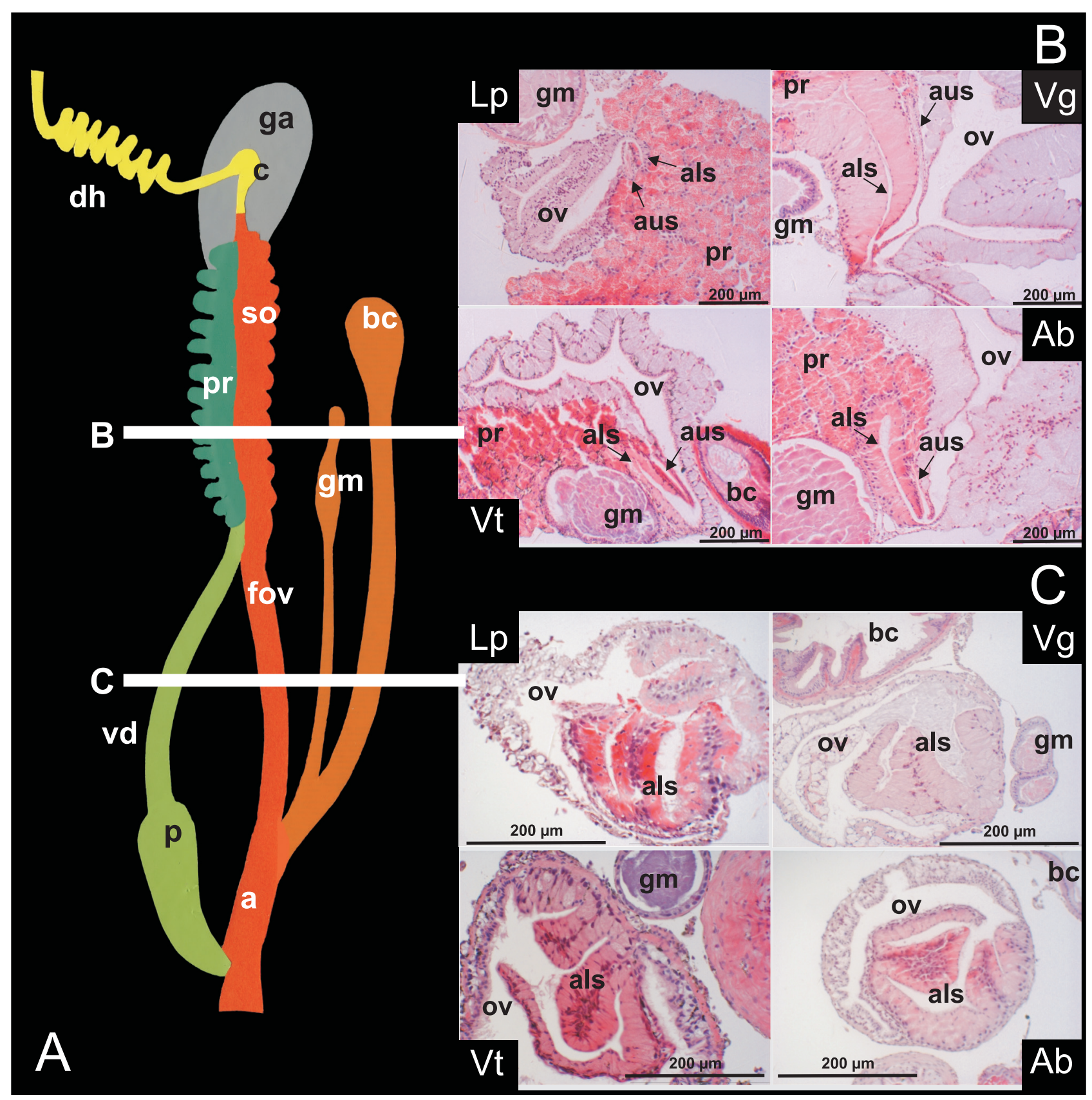

Fig. 1. Anatomical and histological structure of reproductive system of Alinda biplicata (Ab), Laciniaria plicata (Lp), Vestia gulo (Vg) and V. turgida (Vt): A - schematic drawing of the reproductive system, B - section at spermoviduct level, $\mathrm{C}$ - section at free oviduct level; a - atrium, als - allospermiduct, aus - autospermiduct, bc - bursa copulatrix, c - carrefour, dh - hermaphroditic duct, fov - free oviduct, ga - albumen gland, gm - mucus gland, ov - oviduct, p - penis, pr - prostate, so - spermoviduct, vd - vas deferens

groove the prostate (pr) glandular tubules open. The three canals serve to transport three groups of gametes: oviduct - eggs, allospermiduct - allosperm, autospermiduct - autosperm. According to NORDSIECK (1985), the tripartite structure makes the reproductive system semitriaulic. The division into three canals is observed both in the egg retaining/viviparous A. biplicata, V. gulo and V. turgida and in the oviparous L. plicata.

\section{FREE OVIDUCT}

In all four species the free oviduct, externally undivided, is internally divided into two, connected canals: oviduct (ov) and allospermiduct (als) (Fig. 1C). The allospermiduct is formed by a distinct fold which partly separates the main lumen of the organ from four sinuses built by folded epithelium; this is distinctly visible both in the egg-retaining/viviparous $A$. 
biplicata, $V$. gulo and V. turgida and in the oviparous L. plicata. According to STEENBERG (1914), the upper part of the free oviduct, which is a continuation of the spermoviduct after the departure of the vas deferens (vd), contains a distinct fold which divides its interior in two well delimited canals: mucous (= oviduct) and serous (=allospermiduct). Our observations are also corroborated by those of SZYBIAK \& GABAEA (2013) on R. filograna. In the lower part of the free oviduct the walls of the allospermiduct become increasingly thinner, so that at the junction with the spermatheca (bursa copulatrix; bc) only a single lumen of the duct is visible, which is also consistent with the results of other authors (STEENBERG 1914, SZYBIAK \& GABAEA 2013).

\section{HISTOLOGICAL STRUCTURE OF SPERMOVIDUCT}

Histologically, in the spermoviduct (so) (Fig. 2A), whose walls are built of external simple squamous epithelium, smooth muscle cells and connective tissue, all the canals: oviduct (ov), autospermiduct (aus) and allospermiduct (als), and the accompanying prostate (pr), are built of pseudostratified epithelium. The epithelium is composed of large, columnar glandular cells (cc) or columnar cells which in microscope images show no characteristic features of glandular cells (below called non-glandular cells), with large, basally located nuclei, and small supporting cells $(\mathrm{spc})$ with apically located nuclei. The oviduct epithelium (Fig. 2B) is built of two kinds of cells: 1) large, columnar, mucus secreting cells (mc), located near the wall and with flattened basal nuclei, and 2) supporting cells (spc) whose apical parts, of triangular cross-section, face the canal's lumen and contain oval nuclei. Their free surface bears cellular processes (cp). The prostate epithelium has a very similar structure (Fig. 2C), but the cytoplasm of the large columnar cells contains distinct acidophilic granules (hence red colour). They are serous cells (sec), grouped into tubes, and forming the bulk of the gland. The pseudostratified epithelium of the auto- and allospermiduct (Fig. 2D), as in the oviduct, is com-
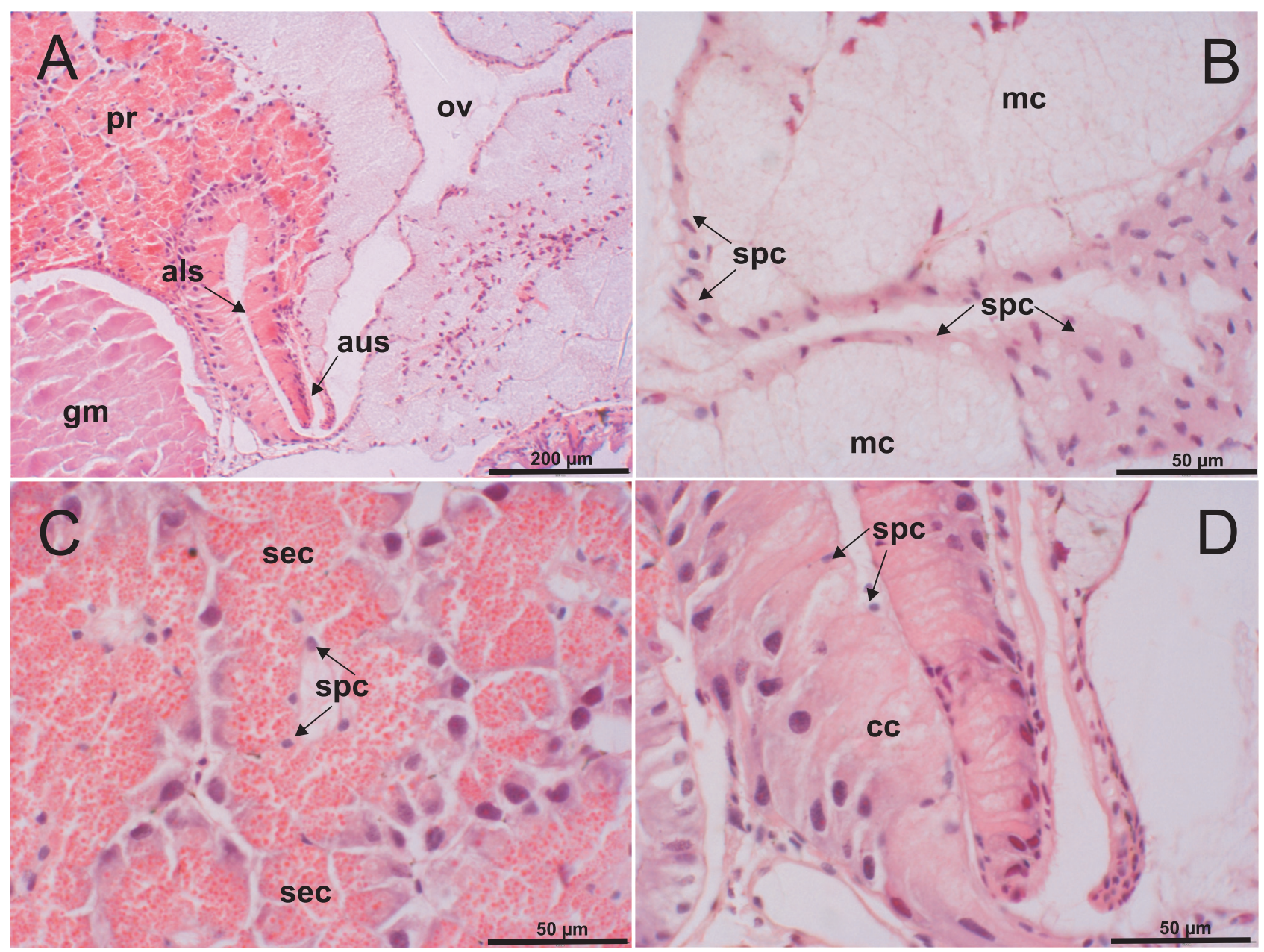

Fig. 2. Alinda biplicata: A - section through spermoviduct, B - oviduct epithelium, C - prostate epithelium, D - epithelium of auto- and allospermiduct; als - allospermiduct, aus - autospermiduct, cc - columnar cells, gm - mucus gland, mc mucus secreting cells, ov - oviduct, pr - prostate, sec - serous cells, spc - supporting cells 
posed of large, columnar and non-glandular cells (cc) and of supporting cells (spc) with cellular processes (cp). The histological structure of the spermoviduct canals does not differ between the viviparous species, egg retainers and oviparous species. Identical structures have been observed in the spermoviduct of Alopiinae and Clausiliinae (STEENBERG 1914, SZYBIAK \& GABAEA 2013). According to STEENBERG (1914), the free surface of supporting cells bears cilia, while SZYBIAK \& GABAEA (2013) point to the presence of cilia and microvilli, though the photographs presented by those authors do not provide unequivocal proof of the presence of such cellular processes. The apical surface of epithelial cells may bear cilia, stereocilia or microvilli, but ultrastructural analysis is required to specify the nature of the processes.

\section{HISTOLOGICAL STRUCTURE OF FREE OVIDUCT}

After the separation of the vas deferens (vd), the spermoviduct (so) passes into the free oviduct (fov), externally undivided, with its walls built of external squamous epithelium, smooth muscle cells and connective tissue. Two canals can be distinguished inside: oviduct (ov) and allospermiduct (als), which are partly connected (Fig. 3A). As in the spermoviduct, the two canals are built of pseudostratified epithelium. In the oviduct, the large, columnar, mucus cells $(\mathrm{mc})$ are glandular cells, while the smaller and much thinner, cuboidal supporting cells (spc), facing the lumen, have apically located nuclei and cellular processes (cp) on their apical surface (Fig. 3B). The epithelium is much folded. The allospermiduct also includes supporting cells (spc) with cellular processes (cp), while the row of large columnar cells differs essentially from that in the spermoviduct. The cells contain distinct acidophilic granules (similar to those found in the prostate cells), and are thus serous cells (sec) (Fig. 3C). The allospermiduct epithelium is folded and forms four distinct sinuses, within which the epithelium surface bears numerous cellular processes (cp). The structure of the free oviduct is the same in the viviparous/egg retaining A. biplicata, V. gulo and V. turgida and the oviparous L. plicata. In all four species, at the junction of the oviduct with the spermatheca (bura copulatrix), the number of muscle cells in the wall increases considerably, whereas the allospermiduct epithelium undergoes gradual reduction till the point of disappearance of the canal's separate lumen. According to STEENBERG (1914), who observed a similar structure of the free oviduct, the allospermiduct secretion is similar to that of the prostate and is most probably the source of nutrition for the allosperm and provides an ambience which makes it possible for them to survive and reach the spermoviduct and the carrefour (c) (receptaculum seminis). STEENBERG (1914) maintains also that in viviparous forms this part of the reproductive system, and especially the serous canal (=allospermiduct), has a simpler structure, compared to oviparous species. He based his conclusions on the observation of the reproductive system of Balea perversa, and his dia-

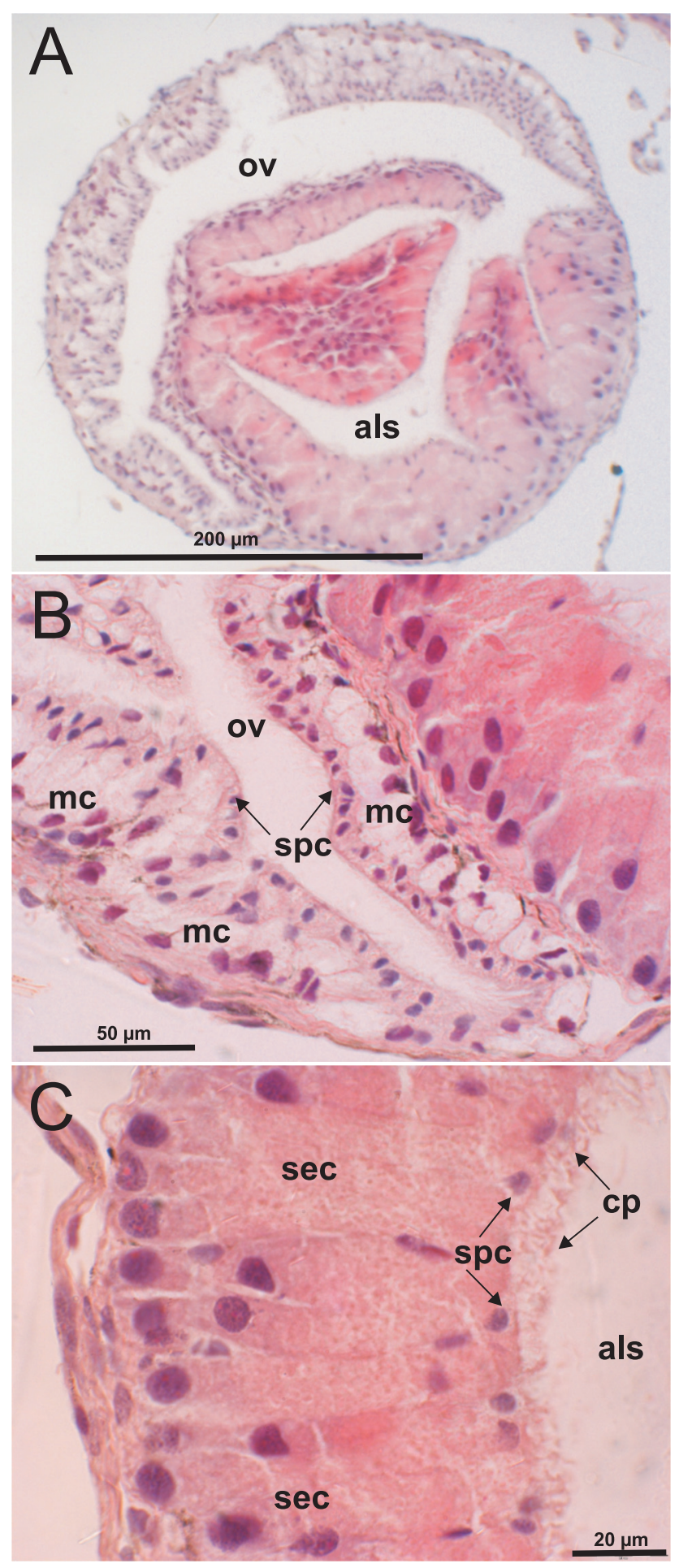

Fig. 3. Alinda biplicata: A - section through free oviduct, B - epithelium of oviduct, C - epithelium of allospermiduct; abbreviations: als - allospermiduct, cp - cellular processes, mc - mucus cells, ov - oviduct, sec - serous cells, spc - supporting cells 
gram of the free oviduct cross-section shows that the studied ducts were filled with eggs, and as a result the oviduct was much stretched, while the allospermiduct was much flattened. A similar situation is observed in gravid A. biplicata (MALTZ unpublished), but the analysis of histological slides of reproductive systems of non-gravid snails shows that the structure of spermoviduct and oviduct of viviparous and oviparous clausiliids is very similar. It can be supposed that the folded pseudostratified epithelium of the oviduct is capable of extensive stretching, enabling the eggs to move freely during oviposition by oviparous forms, and makes possible egg retention in egg retaining/ viviparous snails. Stretching of the spermoviduct and oviduct walls causes their weakening (it is especially evident during dissection, when an egg-filled reproductive system is placed in a hypotonic solution, and the walls burst immediately under the pressure from the swelling eggs). However, the strongly developed allospermiduct epithelium with large, tightly adhering glandular cells, and especially that of the free oviduct, provides a stiffening structure which supports the row of eggs which fill the lower part of the spermoviduct and the oviduct. It probably stabi- lises this part of the reproductive system and at the same time is sufficiently elastic which is important when the animal is moving inside the shell. Such a structure of the clausiliid spermoviduct and free oviduct favours adopting the egg retaining or viviparous strategy. An indirect evidence is provided by the fact that egg retainers/viviparous forms have appeared independently in various door snail subfamilies, among others Alopiinae, Baleinae, Clausiliinae, Mentissoideinae or Phaedusinae (STEENBERG 1914, LIKHAREV 1962, LOOSJES \& LOOSJES-VAN BEMMEL 1973, TOMPA 1979, MAMATKULOV 2007). Besides the reproductive system structure, an important role in switching from oviparity to egg retention/viviparity may have been played by evolving some parental physiological mechanisms regarding the conditions in which the eggs are retained. This hypothesis requires further study.

\section{ACKNOWLEDGEMENTS}

The project was supported by National Science Centre grant (NN303 796740). We are very grateful for helpful comments from anonymous referees.

\section{REFERENCES}

BAUR A. 1990. Intra- and interspecific influences on age at first reproduction and fecundity in the land snail Balea perversa. Oikos 57: 333-337. http://dx.doi. org/10.2307/3565962

BAUR B. 1994. Parental care in terrestrial gastropods. Experientia 50: 5-14. http://dx.doi.org/10.1007/ BF01992042

BLACKBURN D. G. 1999. Viviparity and oviparity: evolution and reproductive strategies. In: KNOBIL T. E., NEILL J. D. (eds). Encyclopedia of reproduction. Academic Press, New York, pp. 994-1003.

FARLEY R. D. 1998. Matrotrophic adaptations and early stages of embryogenesis in the desert scorpion Paruroctonus mesaensis (Vaejovidae). J. Morph. 237: 187-211. http://dx.doi.org/10.1002/(SICI) 1097 4687(199809)237:3 < 187::AID-JMOR1 > 3.0.CO;2-X

FRÖMMING E. 1954. Biologie der mitteleuropäischen Landgastropoden. Duncker und Humblot, Berlin.

GÓMEZ B. J. 2001. Structure and functioning of the reproductive system. In: BARKER G. M. (ed.). The biology of terrestrial molluscs. CABI Publishing, Wallingford, pp. 307330. http://dx.doi.org/10.1079/9780851993188.0307

HELLER J. 2001. Life history strategies, In: BARKER G. M. (ed.). The biology of terrestrial molluscs. CABI Publishing, Wallingford, pp. 413-445. http://dx.doi. org/10.1079/9780851993188.0413

HUDEC V. 1963. Nové poznatky o zeměpisném rozšířeni a anatomii plžu Pseudalinda elata (Rssm.) a Pseudalinda gulo (Blz.). Ćas. Národ. Muz., Řada Př́rodov. 132: 199210.
JĘDRZEJOWSKA I., MAZURKIEWICZ-KANIA M., GARBIEC A., KUbRAKIEWICZ J. 2013. Differentiation and function of the ovarian somatic cells in the pseudoscorpion, Chelifer cancroides (Linnaeus, 1761) (Chelicera: Arachnida: Pseudoscorpionida). Arth. Struct. Dev. 42: 27-36. http://dx.doi.org/10.1016/j.asd.2012.09.004

LIKHAREV I. M. 1962. Klauziliidy (Clausiliidae). Fauna SSSR, N.S. 83, Mollyuski III, 4. Moskva-Leningrad.

Loosjes F. E., LoOSJES-VAN Bemmel A. C. W. 1973. Some anatomical and systematic data on Asiatic Clausiliidae (Gastropoda, Pulmonata). Ann. Zool. 30: 287-317.

LUPU D. 1980. Étude morpho-anatomique comparée concernant la systématique de la famille des Clausiliidae (Gastropoda, Pulmonata) de Roumanie. Trav. Mus. Hist. Nat. "Grigore Antipa" 22: 341-357.

MALTZ T. K., SUliKOWSKA-DrOZD A. 2008. Life cycles of clausiliids of Poland - knowns and unknowns. Ann. Zool. 58: 857-880. http://dx.doi. org/10.3161/000345408X396783

MALTZ T. K., SULIKOWSKA-DrozD A. 2011. Delayed maturation in the genus Vestia P. Hesse (Gastropoda: Pulmonata: Clausiliidae): a model for clausiliid lifecycle strategy. J. Mollus. Stud. 77: 41-53. http://dx.doi. org/10.1093/mollus/eyq040

MALTZ T. K., SulikowsKA-DrozD A. 2012. Life history of Alinda biplicata (Montagu, 1803) (Gastropoda: Pulmonata: Clausiliidae) based on five-year laboratory observations. Ann. Zool. 62: 789-807. http://dx.doi. org/10.3161/000345412X659803 
MALTZ T. K., SUlikowsKA-DROZD A. 2014. Selfing and brooding in Alinda biplicata (Gastropoda: Pulmonata: Clausiliidae) - life history traits of good coloniser. Anim. Biol. 64: 97-113. http://dx.doi.org/10.1163/1570756300002434

MAMATKULOV A. L. 2007. Breeding biology of some East European Clausiliidae species (Mollusca, Pulmonata). Zool. Zh. 86: 403-414.

MARZEC M. 2006. Life cycle of Bulgarica cana (Held, 1836) in laboratory conditions (Gastropoda: Pulmonata: Clausiliidae). Folia Malacol. 14: 92.

NORDSIECK H. 1966. Grundzüge zur vergleichenden Morphologie des Genitalsystems der Schnecken, unter besonderer Berücksichtigung der Stylommatophora. Arch. Moll. 95: 123-142.

NORDSIECK H. 1985. The system of Stylommatophora (Gastropoda), with special regard to the systematic position of the Clausiliidae, I: Importance of the excretory and genital systems. Arch. Moll. 116: 1-24.

NORDSIECK H. 2007. Worldwide door snails (Clausiliidae), recent and fossil. ConchBooks, Hackenheim.

PIECHOCKI A. 1982. Life cycle and breeding biology of Vestia elata (Rossm.) (Gastropoda, Clausiliidae). Malacologia 22: 219-223.

SCHILEYKO A. A. 2000. Treatise on recent terrestrial pulmonate molluscs. 5. Clausiliidea. Ruthenica. Suppl. 2: $1-729$.

Steenberg C. M. 1914. Anatomie des Clausilies danoises. I. Les organes génitaux. Mindeskr. J. Steenstrup 29: $1-44$.

SULIKOWSKA-DROZD A. 2008. Reproduction and growth of Vestia elata (Rossmässler, 1836) (Gastropoda, Clausiliidae) kept under laboratory conditions. Mollusca 26: 99-104.

SULIKOWSKA-DROZD A. 2009. Egg-retention and ovoviviparity in clausiliids of the genus Vestia P. Hesse (Gastropoda: Clausiliidae). J. Mollus. Stud. 75: 351359. http://dx.doi.org/10.1093/mollus/eyp028

SULIKOWSKA-DROZD A., MALTZ T. K. 2012a. Reproduction of Balea (Pseudalinda) fallax (Rossmässler, 1836) (Gastropoda: Pulmonata: Clausiliidae) kept under laboratory conditions. Folia Malacol. 20: 27-34. http:// dx.doi.org/10.2478/v10125-012-0007-1

SULIKOWSKA-DROZD A., MALTZ T. K. 2012b. Balea (Pseudalinda) stabilis (L. Pfeiffer, 1847) (Gastropoda:
Pulmonata: Clausiliidae) kept under laboratory conditions. Folia Malacol. 20: 73-79. http://dx.doi. org/10.2478/v10125-012-0008-0

SULIKOWSKA-DROZD A., MALTZ T. K. 2013. Oviparous reproduction of Vestia ranojevici moravica confirms taxonomic value of life history characters in Carpathian clausiliids (Gastropoda: Pulmonata). Biologia 68: 687695. http://dx.doi.org/10.2478/s11756-013-0209-z

SulikowsKa-Drozd A., MALTZ T. K., STACHYRA P. 2012. Egg retention in the clausiliid Balea (Pseudalinda) fallax (Rossmässler, 1836) from Roztocze (S.E. Poland). Folia Malacol. 20: 35-38. http://dx.doi.org/10.2478/ v10125-012-0004-4

SUliKowSKA-DrOZD A., MALTZ T. K., KAPPES H. 2013. Brooding in a temperate zone land snail: seasonal and regional patterns. Contrib. Zool. 82: 85-94.

SZYBIAK K., GABAŁA E. 2013. Anatomical and histological structure of the spermoviduct in the ovoviviparous snail Ruthenica filograna (Pulmonata, Clausiliidae). Invert. Rep. Dev. 57: 276-286. http://dx.doi.org/10.10 80/07924259.2012.761653

TOMPA A. S. 1979. Studies on the reproductive biology of gastropods: Part 1. The systematic distribution of egg retention in the subclass Pulmonata (Gastropoda). J. Malacol. Soc. Aust. 4: 113-120.

TOMPA A. S. 1984. Land snails (Stylommatophora). In: TOMPA A. S., VERONK N. H., VAN DEN BIGGELAAR J. A. M. (eds). The Mollusca, vol. 7, Reproduction. Academic Press, New York, pp. 47-140.

WEYGOLDT P. 1969. The biology of pseudoscorpions. Harvard University Press, Cambridge, Massachusetts.

WirTh T., BAUR A., BAUR B. 1997. Mating system and genetic variability in the simultaneously hermaphroditic terrestrial gastropod Balea perversa on the Baltic island of Öland, Sweden. Hereditas 126: 199-209. http://dx. doi.org/10.1111/j.1601-5223.1997.00199.x

ZAWISTOWSKI S. 1986. Technika histologiczna. Histologia oraz podstawy histopatologii. PZWL, Warszawa.

Received: January 21st, 2014

Revised: April 9th, 2014

Accepted: April 30th, 2014

Published on-line: July 14th, 2014 